\title{
Comparative Analysis of the Performance of Different Photovoltaic (PV) Technologies Based on PVSyst Thermal Model
}

\author{
Abasi-obot Iniobong Edifon, Nkan Imo Edwin, Ekpe Unwana Macaulay \\ Department of Electrical \& Electronic Engineering, Akwa Ibom State University, Mkpat Enin, Nigeria \\ Email address: \\ iniobongetokebe61@yahoo.com (Abasi-obot I. E.) \\ To cite this article: \\ Abasi-obot Iniobong Edifon, Nkan Imo Edwin, and Ekpe Unwana Macaulay. Comparative Analysis of the Performance of Different \\ Photovoltaic (PV) Technologies Based on PVSyst Thermal Model. Science Journal of Energy Engineering. Vol. 4, No. 6, 2016 , pp. 62-67. \\ doi: $10.11648 /$ j.sjee.20160406.13
}

Received: October 25, 2016; Accepted: November 3, 2016; Published: January 13, 2017

\begin{abstract}
This paper presents the effect of ambient meteorological parameters on the performance of different photovoltaic (PV) technologies based on PVSyst thermal model. The PV technologies considered are: monocrystalline silicon, polycrystalline silicon, amorphous silicon, microcrystalline and cadmium telluride. The study is conducted with hourly meteorological data obtained from PVSyst software meteo-file for Dakar in Senegal, with site coordinate of $14.5^{\circ} \mathrm{N}$ and $17.0^{\circ}$ W. The results show that the different PV technologies have the same cell temperature because PVSyst uses default adsorption coefficient of 0.9 for the different PV technologies. However, the performance of the different PV technologies in response to the cell temperature differs in respect of their thermal coefficient. Among the five PV technologies studied, amorphous silicon has the lowest thermal coefficient and the best thermal response but the worst solar energy conversion efficiency. This means that amorphous silicon would occupy much more space to achieve the same energy output as the other PV technologies studied. Conversely, polycrystalline silicon has the highest thermal coefficient and the worst thermal response but its solar energy conversion efficiency is relatively higher than those of other PV technologies except monocrystalline silicon. The polycrystalline silicon with the same PV module size will yield more energy than its equivalent sized amorphous silicon PV module.
\end{abstract}

Keywords: Renewable Energy, Photovoltaic, Solar Radiation, Cell Temperature, Thermal Loss, Thermal Loss Model, PVSyst, Thermal Coefficient, Cell Efficiency

\section{Introduction}

As the quest for renewable energy increases, PV power systems continue to be one of the dominant choices. However, the suitability of a PV module technology for a particular site depends on some factors that include solar radiation distribution, annual temperature distribution, module temperature coefficient and variations in wind speed $[1,2,3]$. PV module temperature coefficient indicates the level of degradation of the output power of a PV module. Particularly, the electrical conversion efficiency of a PV module depends on cell temperature and this reduces as the cell temperature increases $[1,4]$. The conversion efficiency here refers to the amount of solar energy reaching the PV module and the amount of that energy that can actually been converted to electricity. The cell temperature depends on ambient temperature, solar irradiance, wind speed and module temperature coefficient. All the factors affecting the operation of a PV module are usually taken into account when determining their performance rating, therefore, manufacturers of PV modules usually provide $\mathrm{PV}$ ratings based on Standard Testing Conditions (STC). STC assumes an irradiance of $1000 \mathrm{~W} / \mathrm{m}^{2}$, solar spectrum of air mass of 1.5 and module temperature at $25^{\circ} \mathrm{C}$ [1]. However, PV modules deployed in the field operate over a wide range of environmental conditions and several models have been developed to determine the performance of PV modules under real life conditions. Such models effectively relate the PV cell temperature, PV cell efficiency, PV cell power output and thermal loss to the ambient temperature, wind speed and solar 
irradiance. This paper therefore presents the impact of variation in temperature, wind speed and solar irradiance on the performance of PV modules based on PVSyst thermal model. The thermal model effectively relates the PV cell temperature, PV cell efficiency, PV cell power output and thermal loss to the ambient temperature, wind speed and solar irradiance. Apart from climatic and solar radiation parameters, there are PV technology dependent parameters that also affect PV output and this paper uses the PVsyst thermal model to compare the impact of the ambient climatic and solar radiation parameters on different $\mathrm{PV}$ technologies. The comparison is done in terms of operating cell efficiency, output power, thermal loss and drop in cell efficiency and is carried out on selected PV technologies under the same type of environmental conditions.

\section{Theoretical Background}

Photovoltaic cells are constructed from a variety of semiconductor materials such as silicon, cadmium sulphide, copper sulphide and gallium arsenide, and these cells directly convert solar radiation into electricity. Solar radiation contains photos, which when absorbed by the valence electrons of a PV cell, increases the energy level of such electrons. This causes the electrons to jump from the valence band into the conduction band and as long as a solar cell stays illuminated, the energized electrons are able to flow freely when connected in a circuit [5]. The relationship between the energy in a photon, $E_{p h}$ and the wavelength of light, $\lambda$ is given by

$$
E_{p h}=\frac{h c}{\lambda},
$$

where $h$ is Planck's constant and has the value of $6.625 \times 10^{-34} \mathrm{~J} / \mathrm{s}$, and $C$ is the speed of light. For a cell made from silicon, which has a band gap of $1.11 \mathrm{eV}$, equation (1) reveals that only photons with a wavelength less than $1.12 \mu \mathrm{m}$ can liberate electrons and thus generate electricity. The majority of solar energy that reaches the earth have wavelengths ranging from $0.2 \mu \mathrm{m}$ to $1.2 \mu \mathrm{m}$ and his implies that a significant amount of solar radiation can be converted into electricity. However, regardless of the intensity of the energy carried by a photon, it can only cause one electron to move from the valence band into the conduction band. This accounts for the relatively low efficiency of PV cells [5].

\subsection{PVSyst Cell Temperature Model}

PVSyst is a PV system modeling tool used in simulating and performing technical and economic analysis of PV power [7]. The operation of PVsyst is based on a cell temperature model derived from the Faiman cell temperature model and this is given in (Copper, Bruce, Spooner, Calais, Pryor and Watt, 2013) as:

$$
T_{c}=T_{a}+\left(\frac{\alpha(G)\left(1-\eta_{S T C}\right)}{U_{0}+U_{1}\left(V_{\text {wind }}\right)}\right)
$$

where $\mathrm{T}_{\mathrm{c}}$ represents cell temperature, $\mathrm{T}_{\mathrm{a}}$ is ambient air temperature, $\alpha$ is the adsorption coefficient of the module, $G$ is the irradiance incident on the plane of the module or array in $W / m^{2}, \eta_{S T C}$ is the efficiency of the PV module at STC condition, $U_{0}$ is the constant heat transfer component in $W / m^{2} K, U_{1}$ is the convective heat transfer component in $W / m^{2} K$, and $V_{\text {wind }}$ represents wind speed in $\mathrm{m} / \mathrm{s}$. Both cell and ambient air temperature are in degrees Celsius.

The default values for PVsyst are 0.9 for $\alpha, 0.1$ for $\eta_{S T C}$, no dependence on wind speed, therefore $U_{1}=0$. Other default values are

i. For free-standing arrays, $U_{0}=29 \mathrm{~W} / \mathrm{m}^{2} K, U_{1}=0 \mathrm{~W}$ $/ m^{2} K$

ii. For fully insulated arrays (close roof mount), $U_{0}=15$ $\mathrm{W} / m^{2} K, U_{1}=0 \mathrm{~W} / m^{2} K$

Sun Edison [7] proposed $U_{0}=26 \mathrm{~W} / \mathrm{m}^{2} \mathrm{~K}$ and $U_{1}=1.4$ $\mathrm{W} / \mathrm{m}^{2} \mathrm{~K}$, which are the values that are used in this analysis.

\subsection{Temperature Derating Factor for PV Cell Efficiency and PV Cell Output Power}

According to Brihmat and Mekhtoub [8] the temperature derating factor for the PV cell efficiency and PV cell output power is defined as:

$$
f_{\text {temp }}=1-\left|\beta_{S T C}\right|\left(T_{c}-T_{S T C}\right),
$$

where $f_{\text {temp }}$ represents the dimensionless temperature derating factor and $\beta_{\mathrm{STC}}$ is the power temperature coefficient of module in $\% /{ }^{\circ} \mathrm{C}$. The temperature coefficient of power indicates how strongly the PV array power output depends on the cell temperature, that is, the surface temperature of the PV array. It is a negative value once power output decreases with the increase of cell temperature. $\mathrm{T}_{\mathrm{c}}$ represents the average daily cell temperature, in ${ }^{\circ} \mathrm{C}$ while $\mathrm{T}_{\mathrm{STC}}$ is the cell temperature under standard test conditions $\left(25^{\circ} \mathrm{C}\right)$.

When hourly meteorological data is used, the annual average cell temperature, $\mathrm{T}_{\mathrm{cA}}$ is given as

$$
T_{C A}=\left(\frac{1}{8760}\right)\left[\sum_{i=1}^{i=8760}\left(T_{a(i)}+\left(\frac{\alpha\left(G_{(i)}\right)\left(1-\eta_{S T C}\right)}{U_{0}+U_{1}\left(V_{\text {wind }(i)}\right)}\right)\right)\right]
$$

Therefore the temperature derating factor based on annual average cell temperature, $T_{c A}$ is given as $f_{\text {temp(A) }}$, where

$$
f_{\text {temp }(A)}=1-\left|\beta_{S T C}\right|\left(T_{C}-T_{S T C}\right),
$$

\subsection{The PV Efficiency and Output Power}

PV cell efficiency at STC is given in [8] as

$$
\left.\begin{array}{c}
\eta_{\mathrm{STC}}=\frac{\mathrm{w}_{\mathrm{P}}}{\left(\mathrm{A}_{\mathrm{PV}}\right)\left(\mathrm{G}_{\mathrm{STC}}\right)}=\frac{\mathrm{w}_{\mathrm{P}}}{\left(\mathrm{A}_{\mathrm{PV}}\right)\left(1000 \mathrm{~W} / \mathrm{m}^{2}\right)}, \\
\text { where } A_{\mathrm{PV}}=\frac{\mathrm{w}_{\mathrm{P}}}{\left(\eta_{\mathrm{STC}}\right)\left(1000 \mathrm{~W} / \mathrm{m}^{2}\right)} \\
\text { and } \mathrm{W}_{\mathrm{P}}=\eta_{\mathrm{STC}}\left(\mathrm{A}_{\mathrm{PV}}\right)\left(\mathrm{G}_{\mathrm{STC}}\right)=\eta_{\mathrm{STC}}\left(\mathrm{A}_{\mathrm{PV}}\right)\left(1000 \mathrm{~W} / \mathrm{m}^{2}\right)
\end{array}\right\}
$$

$\eta_{\text {STC }}$ is the maximum power point efficiency under standard test conditions, $\mathrm{W}_{\mathrm{P}}$ is the rated power output of the PV module under standard test conditions in watts, $A_{P V}$ is the surface area of the PV module in $\mathrm{m}^{2}, \mathrm{G}_{\mathrm{STC}}$ is solar irradiance 
at standard test conditions, that is $1 \mathrm{~kW} / \mathrm{m}^{2}$. In [8] it is shown that the PV efficiency varies linearly with temperature as follows:

$$
\begin{gathered}
\eta_{T C}=\eta_{S T C}\left(f_{\text {temp }}\right) \\
\eta_{T C}=\eta_{S T C}\left[1-\left|\beta_{S T C}\right|\left(T_{C A}-T_{S T C}\right)\right],
\end{gathered}
$$

where all the coefficients are as earlier defined. Therefore, similar to equations (7) and (8), the annual average cell efficiency is given as $\eta_{T C A}$ where;

$\eta_{T C A}=\eta_{S T C}\left(f_{\operatorname{temp}(A)}\right)=\eta_{S T C}\left[1-\left|\beta_{S T C}\right|\left(T_{C A}-T_{S T C}\right)\right]$

Given a cell temperature, $\mathrm{T}_{\mathrm{c}}$ and solar irradiance incident on the plane of the PV module, G, the PV power output is given by Omar, Hussin, Shaari and Sopian, [9]: as

$$
\left.\begin{array}{c}
W_{T c}=W_{P}\left(\frac{G}{G_{S T C}}\right)\left(f_{\text {temp }}\right) \\
W_{T C}=W_{P}\left(\frac{G}{G_{S T C}}\right)\left[1-\left|\beta_{S T C}\right|\left(T_{C}-T_{S T C}\right)\right]
\end{array}\right\}
$$

Using hourly meteorological data, the expected annual energy output of the PV $\left(\mathrm{E}_{\mathrm{AE}}\right)$ is given as the summation of the power deliver in the 8760 hours per annum. That is

$$
\mathrm{E}_{\mathrm{AE}}=\sum_{\mathrm{i}=1}^{\mathrm{i}=8760}\left(\mathrm{~W}_{\mathrm{P}}\left(\frac{\mathrm{G}_{\mathrm{i}}}{G_{S T C}}\right)\right)
$$

Equation (11) is given in watt-hours. The actual annual energy output of the PV when only the temperature derating factor is considered is given as $\mathrm{E}_{\mathrm{AA}}$, where;

$$
E_{A A}=\left[1-\left|\beta_{S T C}\right|\left(T_{C A}-T_{S T C}\right)\right]\left(\sum_{i=1}^{i=8760}\left(W_{P}\left(\frac{G_{i}}{G_{S T C}}\right)\right)\right)
$$

The Annual Average Percentage Thermal Loss (ATL\%) is then given as

$$
(\mathrm{ATL} \%)=\left|\beta_{\text {STC }}\right|\left(\mathrm{T}_{\mathrm{CA}}-\mathrm{T}_{\mathrm{STC}}\right)
$$

The Annual Thermal Loss (ATL) in Wh or $\mathrm{kWh}$ is given as

$$
(A T L)=\left[\left|\frac{\beta_{S T C}}{100}\right|\left(T_{C A}-T_{S T C}\right)\right]\left(\sum_{i=1}^{i=8760}\left(W_{P}\left(\frac{G_{i}}{G_{S T C}}\right)\right)\right)
$$

\section{The Simulation Process}

The simulation is conducted with hourly meteorological data obtained from PVSyst software meteo-file for Dakar in Senegal, West Africa. The site coordinate for the data is $14.5^{\circ}$ $\mathrm{N}, 17.0^{\circ} \mathrm{W}$ and altitude of $5 \mathrm{~m}$. The complete data consists of 8760 (one-year) hourly meteorological data. The parameters of the PV technologies used in the study are given in Table 1.

\begin{tabular}{|c|c|c|c|c|c|}
\hline PV Technology & $\begin{array}{l}\text { Monocrystalline } \\
\text { Silicon (m-Si) }\end{array}$ & $\begin{array}{l}\text { Polycrystalline } \\
\text { Silicon (p-Si) }\end{array}$ & $\begin{array}{l}\text { Amorphous } \\
\text { Silicon (a-Si) }\end{array}$ & $\begin{array}{l}\text { Microcrystalline } \\
(\mu \mathrm{c}-\mathrm{Si})\end{array}$ & $\begin{array}{l}\text { Cadmium Telluride } \\
\text { (CdTe) (CdTe) }\end{array}$ \\
\hline Module efficiency $\eta_{S T C}(\%)$ & 18.4 & 14.1 & 6.0 & 9.5 & 10.7 \\
\hline Temperature coefficient of maximal powe $\beta_{\text {STC }}\left(\% /{ }^{\circ} \mathrm{C}\right)$ & -0.38 & -0.45 & -0.19 & -0.24 & -0.25 \\
\hline STC Rated Output (Wp) in watts & 100 & 100 & 100 & 100 & 100 \\
\hline
\end{tabular}
PVsyst default value for the adsorption coefficient of the module $(\alpha)$ is 0.9 . The cell temperature is computed using the following set of published [7] combinations of values, $\mathrm{U}_{0}=26 \mathrm{~W} / \mathrm{m}^{2} \mathrm{~K}$ and $\mathrm{U}_{1}=1.4 \mathrm{~W} / \mathrm{m}^{2} \mathrm{~K}[10,11]$. Table 1 shows other parameters considered in the simulation.

Table 1. Parameters of the PV Technologies Considered in the Simulation.

\section{Results and Discussion}

An extract of one-day hourly meteorological data for Dakar is given in Table 2 while Figure 1 shows the cell temperature computed for each of the hours in that day.

From Table 2 and Figure 1, the cell temperature is equal to the ambient temperature in those occasions where the solar irradiance is zero. However, the cell temperature is greater than the ambient temperature in those occasions where the solar irradiance is not equal to zero. The peak of the solar irradiance and cell temperature occurred at about 12 noon while the peak ambient temperature occurred between $2 \mathrm{pm}$ and $3 \mathrm{pm}$. In all, the wind speed is constant at $5 \mathrm{~m} / \mathrm{s}$.

With average cell temperature of $34.3^{\circ} \mathrm{C}$ for the day, STC temperature of $25^{\circ} \mathrm{C}$ and $\beta_{S T C}=-0.38 \% /{ }^{\circ} \mathrm{C}$ for the monocrystalline silicon $\mathrm{PV}$, the temperature derating factor for that day for that particular PV is

$$
f_{\text {temp }(A)}=1-\left|\frac{\beta_{S T C}}{100}\right|\left(T_{C A}-T_{S T C}\right)=1-\left(\left|\frac{-0.38}{100}\right|(34.3-25)\right)=1-0.03534=0.96466
$$

Meanwhile, the Monocrystalline Silicon PV cell efficiency at STC is $18.4 \%$ so, the derated cell efficiency for that day is

$$
\eta_{\mathrm{TcA}}=\eta_{\mathrm{STC}}\left(f_{\text {temp }(A)}\right)=0.96466 \times 18.4 \%=17.45 \%
$$

From table 2, the total irradiation for the day is $24 \times 316.75=7602 \mathrm{~W} / \mathrm{m}^{2}$. The power output from the monocrystalline silicon PV for the day is

$$
\mathrm{W}_{\mathrm{Tc}}=\mathrm{W}_{\mathrm{P}}\left(\frac{\mathrm{G}}{\mathrm{G}_{\mathrm{STC}}}\right)\left(\mathrm{f}_{\mathrm{temp}}\right)=100\left(\frac{7602}{1000}\right)(0.96466)=733.334532 \mathrm{Wh} \text { per day }
$$


The thermal loss for the day for the monocrystalline silicon PV is

$$
\mathrm{W}_{\mathrm{P}}\left(\frac{\mathrm{G}}{\mathrm{G}_{\mathrm{STC}}}\right) \times\left(\left|\frac{-0.38}{100}\right|(34.3-25)\right)=100\left(\frac{7602}{1000}\right) \times 0.03534=26.865468 \mathrm{Wh}
$$

The percentage thermal loss is therefore equal to

$$
\left|\beta_{\mathrm{STC}}\right|\left(\mathrm{T}_{\mathrm{cA}}-\mathrm{T}_{\mathrm{STC}}\right)=|-0.38|(34.3-25)=3.534 \%
$$

Table 2. A One-day hourly meteorological data for Dakar and the corresponding cell temperature.

\begin{tabular}{llllll}
\hline $\begin{array}{l}\text { Hours of the } \\
\text { day }\end{array}$ & $\begin{array}{l}\text { Global Irradiation on the } \\
\text { Tilted Plane }\left(\mathbf{W} / \mathbf{m}^{\mathbf{2}}\right)\end{array}$ & $\begin{array}{l}\text { Ambient Temperature, Ta } \\
\left({ }^{\mathbf{C}} \mathbf{C}\right)\end{array}$ & $\begin{array}{l}\text { Wind Speed, Vwind } \\
(\mathbf{m} / \mathbf{s})\end{array}$ & Cell Temperature, Tc $\left({ }^{\circ} \mathbf{C}\right)$ & $\begin{array}{l}\text { Hours of the } \\
\text { day }\end{array}$ \\
\hline 0 & 0 & 23.1 & 5 & 23.1 & 12 \\
1 & 0 & 23.1 & 5 & 23.1 & 13 \\
2 & 0 & 22.6 & 5 & 22.6 & 14 \\
3 & 22.3 & 5 & 22.3 & 15 \\
4 & 0 & 21.6 & 5 & 22.6 & 16 \\
5 & 0 & 22.5 & 5 & 22.5 & 17 \\
6 & 0 & 22.5 & 5 & 30.9 & 18 \\
7 & 0 & 21.8 & 5 & 37.8 & 20 \\
8 & 408 & 24.4 & 5 & 41.7 & 21 \\
9 & 603 & 26.2 & 5 & 47.1 & 22 \\
10 & 696 & 28.3 & 5 & 53.0 & 23 \\
11 & 846 & 31.2 & 5 & \\
\hline
\end{tabular}

Table 2. Continue.

\begin{tabular}{llll}
\hline Global Irradiation On The Tilted Plane $\left(\mathbf{W} / \mathbf{m}^{\mathbf{2}}\right)$ & Ambient Temperature, Ta $\left({ }^{\circ} \mathbf{C}\right)$ & Wind Speed, Vwind $(\mathbf{m} / \mathbf{s})$ & Cell Temperature, Tc $\left({ }^{\circ} \mathbf{C}\right)$ \\
\hline 1055 & 34.8 & 5 & 58.3 \\
976 & 36.7 & 5 & 58.4 \\
870 & 37.2 & 5 & 56.6 \\
720 & 37.2 & 5 & 53.2 \\
339 & 36.2 & 5 & 43.7 \\
108 & 33.1 & 5 & 35.5 \\
0 & 29.8 & 5 & 29.8 \\
0 & 27.2 & 5 & 27.2 \\
0 & 24.6 & 5 & 24.6 \\
0 & 24 & 5 & 24.0 \\
0 & 22.7 & 5 & 22.7 \\
0 & 22.1 & 5 & 22.1 \\
316.75 & 27.3 & 5 & 34.34913 \\
\hline
\end{tabular}

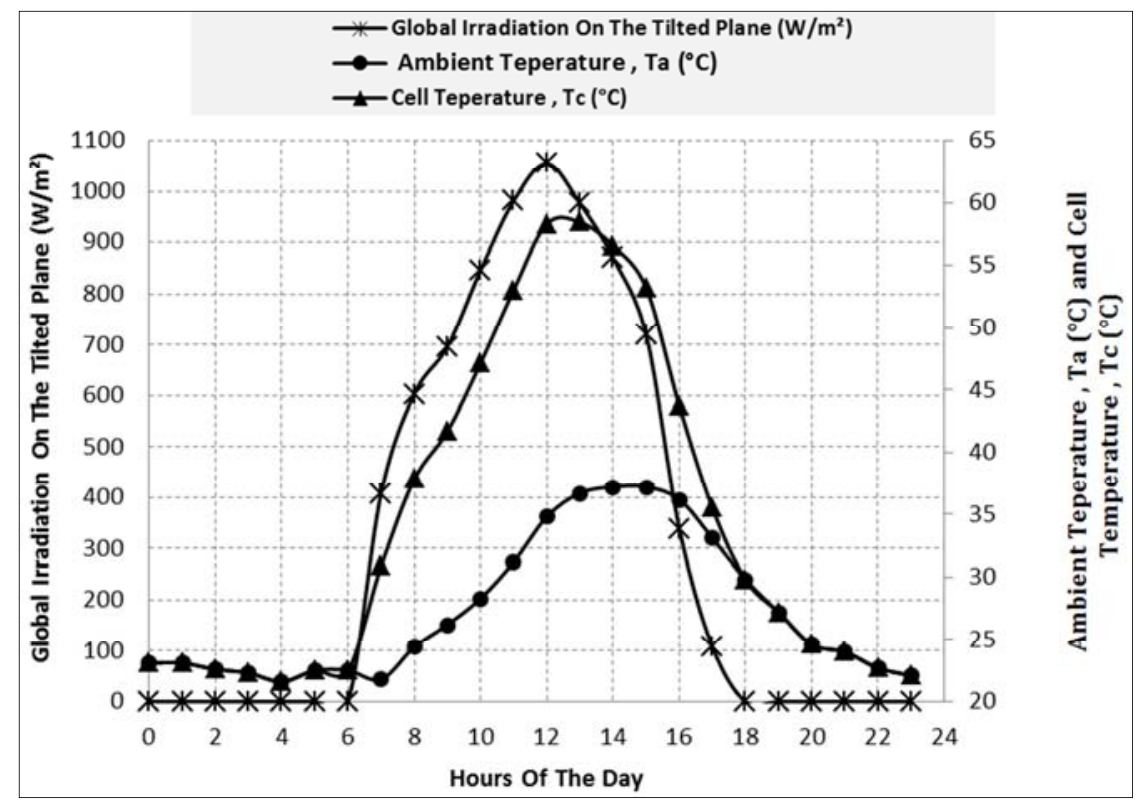

Figure 1. One-day hourly meteorological data for Dakar and the corresponding cell temperature. 
Table 3 shows the results of the effect of ambient meteorological parameters on the performance of the different PV technologies. In row 9 of Table 3, the average annual cell temperature of the $\mathrm{PV}$ technologies are the same $\left(41.707^{\circ} \mathrm{C}\right)$ because the same adsorption coefficient of the module $(\alpha=$ 0.9 ) is used for all the PV technologies. Out of the 8760 hours in a year, the solar irradiance is zero in more than half of the time, in those cases the PV output is zero. Also, in calculating the average annual cell temperature, out 4309 hours it is only in about $49.19 \%$ that the solar irradiance is above zero and hence contributed to the yearly energy yield of the PV module. Consequently, the annual average cell temperature is the total cell temperature when the solar irradiance is above zero divided by 4309 . That gives the annual cell temperature of $41.707^{\circ} \mathrm{C}$. When the total cell temperature is computed for all the 8760 hours and then divided by the 8760 , the annual cell temperature is $32.65^{\circ} \mathrm{C}$ which includes those temperatures that do not contribute to the PV energy yield.

Polycrystalline silicon has the lowest (worst) temperature derating factor (column 4 row 11 of Table 3) and hence it has the lowest (worst) energy output (column 4 row 12 of Table 3) as well as the highest (worst) thermal loss output (column 4 row 13 of Table 3 ). Column 4 row 4 of Table 3 shows that polycrystalline silicon has the highest (worst) temperature coefficient of $-45 \% /{ }^{\circ} \mathrm{C}$ which is the reason for the bad thermal behavior.

Row 15 of Table 3 shows normalised energy output which is the ratio of the PV annual energy output to the lowest PV annual energy output, which is $208157.709 \mathrm{Wh}$ per year. The normalised thermal loss is also obtained by dividing the PV thermal loss with the highest (worst) PV thermal loss which is $16921.891 \mathrm{Wh}$ per year. The normalised percentage thermal loss is also obtained by dividing the PV thermal loss with the lowest (worst) PV output which is 208157.709Wh per year.

Table 3. The Result of the Effect of Ambient Meteorological Parameters on the Performance of Different PV Technologies.

\begin{tabular}{|c|c|c|c|c|c|c|}
\hline 1 & 2 & 3 & 4 & 5 & 6 & 7 \\
\hline 2 & PV Technology & $\begin{array}{l}\text { Monocrystalline } \\
\text { Silicon (m-Si) }\end{array}$ & $\begin{array}{l}\text { Polycrystalline } \\
\text { Silicon (p-Si) }\end{array}$ & $\begin{array}{l}\text { Amorphous } \\
\text { Silicon (a-Si) }\end{array}$ & $\begin{array}{l}\text { Microcrystalline } \\
(\mu \mathrm{c}-\mathrm{Si})\end{array}$ & $\begin{array}{l}\text { Cadmium Telluride } \\
\text { (CdTe) (CdTe) }\end{array}$ \\
\hline 3 & Module efficiency (\%) & 18.4 & 14.1 & 6 & 9.5 & 10.7 \\
\hline 4 & Temperature coefficient of maximal power $\left(\% /{ }^{\circ} \mathrm{C}\right)$ & -0.38 & -0.45 & -0.19 & -0.24 & -0.25 \\
\hline 5 & STC Rated Output (Wp) in watts & 100 & 100 & 100 & 100 & 100 \\
\hline 6 & PV Area $\left(\mathrm{m}^{\wedge} 2\right)$ & 0.54 & 0.71 & 1.67 & 1.05 & 0.93 \\
\hline 7 & Normalised PV Area & 1.00 & 1.30 & 3.07 & 1.94 & 1.72 \\
\hline 8 & $\begin{array}{l}\text { Total Global Irradiation On The Tilted Plane }\left(\mathrm{W} / \mathrm{m}^{2}\right) \\
\text { per year }\end{array}$ & 2250796.000 & 2250796.000 & 2250796.000 & 2250796.000 & 2250796.000 \\
\hline 9 & $\begin{array}{l}\text { Total Number Of Hours For The Solar Irradiation } \\
\text { Above Zero }\end{array}$ & 4309.000 & 4309.000 & 4309.000 & 4309.000 & 4309.000 \\
\hline 10 & Average Annual Cell Temperature $\left({ }^{\circ} \mathrm{C}\right)$ & 41.707 & 41.707 & 41.707 & 41.707 & 41.707 \\
\hline 11 & ftemp & 0.937 & 0.925 & 0.968 & 0.960 & 0.958 \\
\hline 12 & Energy Output (Wh) per year & 210790.003 & 208157.709 & 217934.802 & 216054.591 & 215678.549 \\
\hline 13 & Thermal Loss (Wh) Per year & 14289.597 & 16921.891 & 7144.798 & 9025.009 & 9401.051 \\
\hline 14 & $\%$ Thermal Loss & 6.349 & 7.518 & 3.174 & 4.010 & 4.177 \\
\hline 15 & Normalised Energy Output per year & 1.013 & 1.000 & 1.047 & 1.038 & 1.036 \\
\hline 16 & Normalised Thermal Loss Per year & 0.844 & 1.000 & 0.422 & 0.533 & 0.556 \\
\hline 17 & Normalised \% Thermal Loss & 6.865 & 8.129 & 3.432 & 4.336 & 4.516 \\
\hline
\end{tabular}

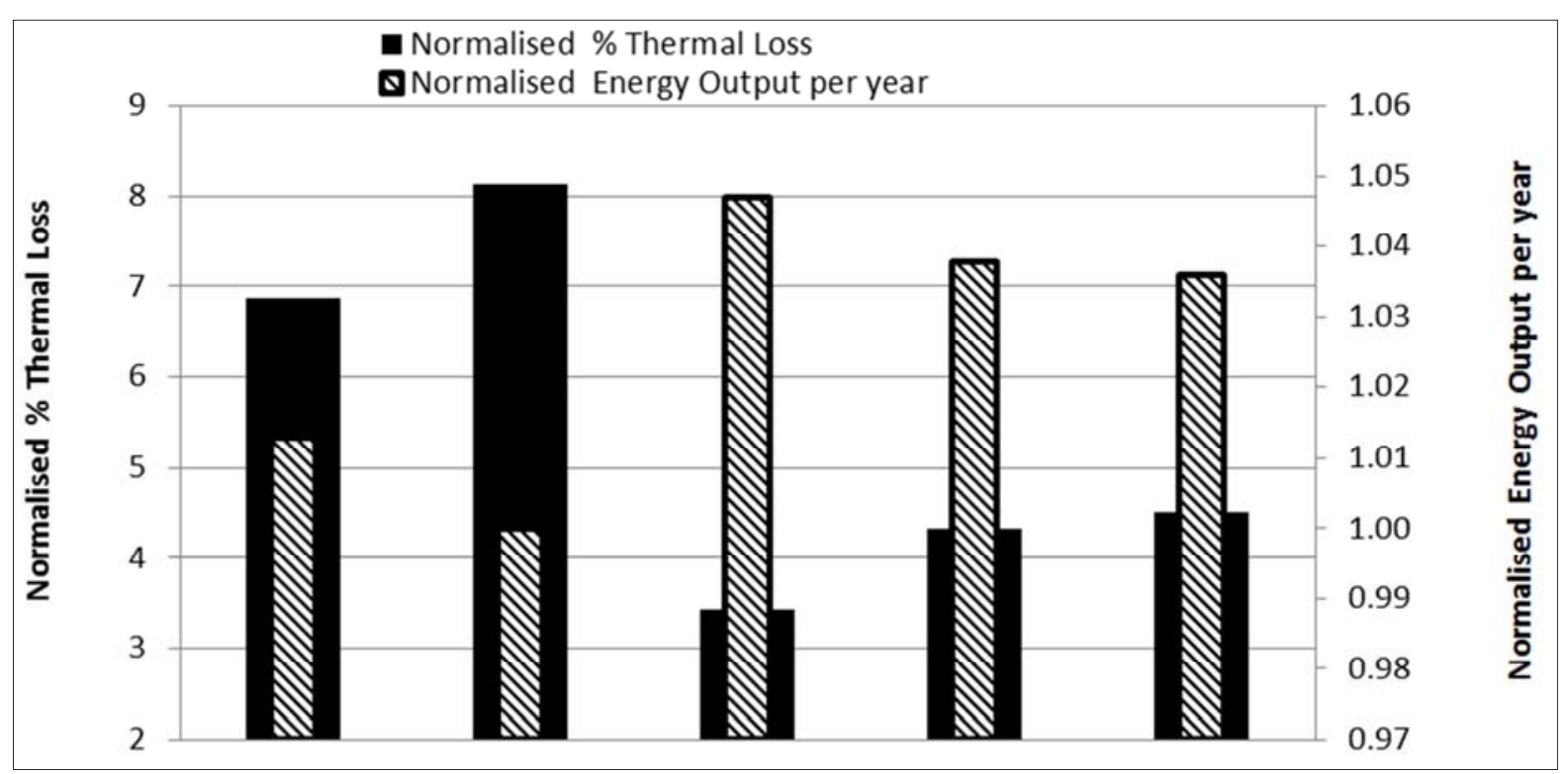

Figure 2. Normalised Energy Output Per Year and Normalised \% Thermal Loss For The PV Technologies. 
From the normalised figures in Table 3 and Figure 2, the amorphous silicon with the lowest temperature coefficient of $-19 \% /{ }^{\circ} \mathrm{C}$ has the highest normalised annual energy output and the lowest normalised annual thermal loss. However, the amorphous silicon PV module used to achieve that is about three times the size of the monocrystalline silicon PV modules and about 2.5 times the size of the polycrystalline silicon PV module. So, the polycrystalline silicon PV module of the same size as the amorphous silicon PV module will give much higher energy yield. However, a comparative cost analysis is not conducted in this paper even though in practice a multidimensional comparative analysis is required in the selection of PV technology for any site.

\section{Conclusion}

The effect of ambient meteorological parameters on the performance of different PV technologies based on PVSyst thermal model has been presented. Even though the different PV technologies were exposed to the same ambient temperature, their cell temperature and output performance differs due to their unique thermal coefficients. Among the five PV technologies studied, amorphous silicon was found to have the best thermal response but the worst solar energy conversion efficiency. This makes the amorphous silicon to occupy much more space in order to achieve the same energy output as the other PV technologies studied.

\section{References}

[1] Dash, P. K. (2015). Effect of Temperature on Power Output from Different Commercially available Photovoltaic Modules. International Journal of Engineering Research and Applications, 1 (5), 148-151.

[2] Guarracino, I., Mellor, A., Ekins-Daukes, N. J., \&Markides, C. N. (2016). Dynamic coupled thermal-and-electrical modelling of sheet-and-tube hybrid photovoltaic/thermal (PVT) collectors Applied Thermal Engineering.
[3] Araneo, R., Grasselli, U., \& Celozzi, S. (2014). Assessment of a practical model to estimate the cell temperature of a photovoltaic module. International Journal of Energy and Environmental Engineering, 5 (1), 1-15.

[4] Vokas, G., Christandonis, N., \& Skittides, F. (2006). Hybrid photovoltaic-thermal systems for domestic heating and cooling - a theoretical approach. Solar energy, 80 (5), 607-615.

[5] Kalogirou, S. A. (2009). Solar Energy Engineering: Processes and Systems. London: Academic Press. pp 109-215.

[6] Mermoud, A. (2010). Modeling Systems Losses in PVsyst. Institute of the Environmental Sciences Group of energyPVsyst, Universitè de Genève.

[7] SunEdison (2015) Obtaining Accurate Energy Harvest Estimations From SunEdison Modules Using PVSyst v6.23 Solar Simulator. PVSyst_v6.23_Technical Note.2015Available at:

http://www.sunedison.com/sites/default/files/file-uploads/solar -material-resource/SE_PVSyst_Tech_Note_0.pdf Accessed on $3^{\text {rd }}$ September 2016.

[8] Brihmat, F., \& Mekhtoub, S. (2014). PV Cell Temperature/PV Power Output Relationships Homer Methodology Calculation. In ConférenceInternationale des Energies Renouvelables" CIER'13"/International Journal of Scientific Research \& Engineering Technology (Vol. 1, No. 02). International Publisher \& C. O.

[9] Omar, A. M., Hussin, M. Z., Shaari, S., \&Sopian, K. (2014). Energy yield calculation of the grid connected photovoltaic power system. In 8th International Conference on Renewable Energy Sources (RES) (pp. 162-167).

[10] Schwingshackl, C., Petitta, M., Wagner, J. E., Belluardo, G., Moser, D., Castelli, M.,... \& Tetzlaff, A. (2013). Wind effect on PV module temperature: Analysis of different techniques for an accurate estimation. Energy Procedia, 40, 77-86.

[11] Koehl, M., Heck, M., Wiesmeier, S., \& Wirth, J. (2011). Modeling of the nominal operating cell temperature based on outdoor weathering. Solar Energy Materials and Solar Cells, 95 (7), 1638-1646. 